\title{
ÇORAK GÖLÜ (BURDUR) HAVZASININ HİDROJEOLOJİK ÖZELLİKLERİ VE SU KALİTESİ
}

\author{
Şehnaz ȘENER ${ }^{*}$, Erhan ŞENER², İskender GÜLLE ${ }^{3}$
}

\begin{abstract}
1Süleyman Demirel Üniversitesi, Mühendislik Fakültesi, Jeoloji Mühendisliği Bölümü, Isparta, Türkiye 22üleyman Demirel Üniversitesi, Uzaktan Algılama Araştırma ve Uygulama Merkezi, Isparta, Türkiye ${ }^{3}$ Mehmet Akif Ersoy Üniversitesi, Fen Edebiyat Fakültesi, Biyoloji Bölümü, Burdur, Türkiye
\end{abstract}

\begin{tabular}{|c|c|}
\hline Anahtar Kelimeler & Öz \\
\hline $\begin{array}{l}\text { Corak Gölü, } \\
\text { Hidrojeoloji, }\end{array}$ & $\begin{array}{l}\mathrm{Bu} \text { çalışmada, Çorak Gölü havzasının jeolojik ve hidrojeolojik özellikleri } \\
\text { incelenmiștir. Ayrıca, havzadaki su kaynaklarının kalitesi değerlendirilmiştir. Çorak }\end{array}$ \\
\hline Sulak alan. & $\begin{array}{l}\text { Gölü mevsimlik su tutan bir göl olup yaklaşık } 10 \mathrm{~km}^{2} \text { lik bir alana sahiptir. Göl } \\
\text { havzasında allokton ve neootokton konumlu farklı yaş ve litolojiye sahip kaya } \\
\text { birimleri yüzeylemektedir. Gölün en önemli beslenim kaynağı yağıştır ve havzaya } \\
\text { düşen maksimum yağış miktarı } 443.91 \mathrm{~mm} \text { olarak hesaplanmıştır. Bölgede } \\
\text { yeraltısuyu derinlikleri } 2.2 \mathrm{~m} \text { ile } 36.1 \mathrm{~m} \text { arasında değișmekte olup yeraltısuyu akım } \\
\text { yönü genel olarak Çorak Gölü'ne doğrudur. Su kalite değerlendirmelerine göre } \\
\text { havzadaki yüzey ve kaynak sularının tamamının genel olarak I. su kalite sınıfında olduğu } \\
\text { belirlenmiştir. }\end{array}$ \\
\hline
\end{tabular}

\section{HYDROGEOLOGICAL PROPERTIES AND WATER QUALITY OF ÇORAK LAKE (BURDUR) BASIN}

\section{Keywords \\ Çorak Lake, Hydrogeology, Wetland.}

\begin{abstract}
In this study, geological and hydrogeological properties of the Çorak Lake were investigated. In addition, the water quality of the water resources in the basin was evaluated. Çorak Lake that holds seasonal water and has an area of $10 \mathrm{~km}^{2}$.The allochtonous and neo-autochthonous rock units are observed with different age and lithology in the lake basin. The most important recharge source of the lake is rainfall and the maximum rainfall in the basin is $443.91 \mathrm{~mm}$. Groundwater depths vary between $2.2 \mathrm{~m}$ and $36.1 \mathrm{~m}$ in the region and groundwater flow direction is towards the Çorak Lake. Based on water quality assessments ,the surface and spring waters in the basin are classified as $1^{\text {st }}$ water quality.
\end{abstract}

\begin{abstract}
Alıntı / Cite Mühendislik Bilimleri ve Tasarım Dergisi, 7(1), 103-114.

Yazar Kimliği / Author ID (ORCID Number)

Ş. Şener, 0000-0003-3191-2291

E. Şener, 0000-0001-6263-8366

İ. Gülle, 0000-0003-3298-3657

\section{Giriş}

Sulak Alanlar biyolojik üretimin en yüksek olduğu ekosistemlerdir. Sulak alanların başlıca işlevleri olarak; içme suyu sağlama, taşkın kontrolü, yeraltısularının beslenmesi, sediman ve besin depolama, iklim değişikliğinin kontrolü, doğal arıtım, tarım, hayvancılık, balıkçılık, saz kesimi ve turizm sayılabilir. Küresel iklim değişikliği sürecinde, dünyanın çeşitli yerlerinde yaşanacak iklimsel değişikliklerin kontrolünde sulak alanlar önem kazanmaktadır.
\end{abstract}

Şener, Ş., Şener, E., Gülle, İ., (2019). Çorak Gölü (Burdur) Havzasının Hidrojeolojik Özellikleri Ve Su Kalitesi,
24.11.2018

04.12 .2018

05.12 .2018

25.03.2019
Ramsar (1971)'a göre sulak alanlar; “alçak gelgitte derinliği 6 m’yi aşmayan deniz suyu alanlarını kapsamak üzere, doğal yada yapay, sürekli yada geçici, durgun yada akar, tatll, acı ya da tuzlu bütün sular ile bataklık, sazlık, ıslak çayırlar ve turbalıklar" olarak tanımlanmaktadır. Ülkemiz sulak alanlar bakımından Avrupa ve Ortadoğu'nun en önemli ülkelerinden biridir. 17/5/1994 tarihli ve 21937 sayılı Resmî Gazete'de yayımlanan Özellikle Su Kuşları Yaşama Ortamı Olarak Uluslararası Öneme Sahip Sulak Alanlar Hakkında Sözleşme hükümlerine dayanılarak

\footnotetext{
* ilgili yazar / Corresponding author: sehnazsener@sdu.edu.tr, +90-246-211-1324, +90246-211-3085
} 
Türkiye'de 14 adet Ramsar Alanı ile 38 adet Ulusal Öneme Haiz Sulak Alan bulunmaktadır. Çorak Gölü Sulak Alanı da 01.07.2015 tarihinde Ramsar ve Ulusal Öneme Haiz Sulak Alanlar konusunda yapılan revizyon sırasında Ulusal Öneme Haiz Sulak Alan olarak tescil edilmiştir.

Sulak alanın su kütleleriyle bağlantısı kesilir, su rejimi bozulur veya ekolojik sağlığı bozulursa bu sulak alanın zarar görerek fonksiyonlarını yitirmesine sebep olmaktadır (Güney, 2014). Çalışma alanını oluşturan ve ülkemizin önemli sulak alanlarından biri olan Çorak Gölü ülkemizdeki 26 büyük havzadan biri olan Burdur Havzası içerisinde bulunmaktadır. Göl yaklaşık son 50 yıldır mevsimlik olarak su tutan bir göl olup son yıllarda havzada sayıları giderek artan göletler, sondaj tesisleri, tarım-hayvancılık faaliyetleri ve doğal taş ocağı tesislerinin de eklenmesiyle durum daha ciddi boyutlara ulaşmıştır. $\mathrm{Bu}$ çalışmada, Çorak Gölü havasının hidrolojik, ve hidrojeolojik incelemesi yapılarak su kalitesi değerlendirilmiştir.

\section{Bilimsel Yazın Taraması}

Çorak Gölü Burdur Gölleri Havzası sınırları içinde yer alan küçük göllerinden birisidir. Yaklașık 9,98 km²'lik bir yüzey alanına sahip olan Çorak Gölü kapalı havza özelliğindedir. Yaklaşı 318,5 km²'lik bir alanı kapsamaktadır. Tektonik bir oluşuma sahip olan çalışma alanı daha önce birçok araştırmacı tarafından jeolojik ve yapısal özellikleri bakımından incelenmiştir.

Çalışma alanı Güney Batı Anadolu'da Isparta büklümü olarak bilinen coğrafik oluşumun kuzey batısında yer almaktadır. Göl havzası bugünkü yapısını Alpin orojenezi ile kazanmış olan ve Ketin (1966) tarafından Toridler olarak tanımlanan tektonik birlik içindedir. Bölgede daha önceden araştırma yapmış birçok araştırmacıya göre Isparta Açısı şimdiki konumunu neotektonik dönemde kazanmıştır (Kissel ve Poisson, 1986; Piper vd., 2002; Yağmurlu vd., 2007).

Ulusal Öneme Haiz Sulak Alan olarak tescilli olan Çorak Gölü'nün en önemli sorunu ciddi su kaybının olmasıdır. $\mathrm{Bu}$ çalışma kapsamında, Çorak Gölü havzasının hidrojeolojik incelemesinin yapılarak bölgedeki hidrojeolojik yapının ve su kalitesinin ortaya konulması, doğal bir kaynak olan Çorak Gölü Sulak Alanı'nın korunması ve sürdürülebilir yönetimi açısından büyük önem taşımaktadır.

\section{Materyal ve Yöntem}

Çorak Gölü Havzası coğrafik olarak Akdeniz Bölgesi'nde, Burdur, Denizli ve Afyon il sınırlarının kesiştiği bölgede olup yaklaşık 318.5 km²'lik bir alanı kapsamaktadır (Şekil 1). Çorak Gölü Havzasına ait sayısal topografik haritalardan elde edilen Sayısal Yükseklik Modeli'ne göre havzadaki en düşük kot $954,22 \mathrm{~m}$ ve en yüksek kot ise 2031.40 m'dir. Ayrıca havzanın ortalama yüksekliği 1256.74 m'dir. Havzadaki eğimler ise $0-55.67^{\circ}$ arasında değişmekle birlikte ortalama eğim $10.9^{\circ}$ dir.

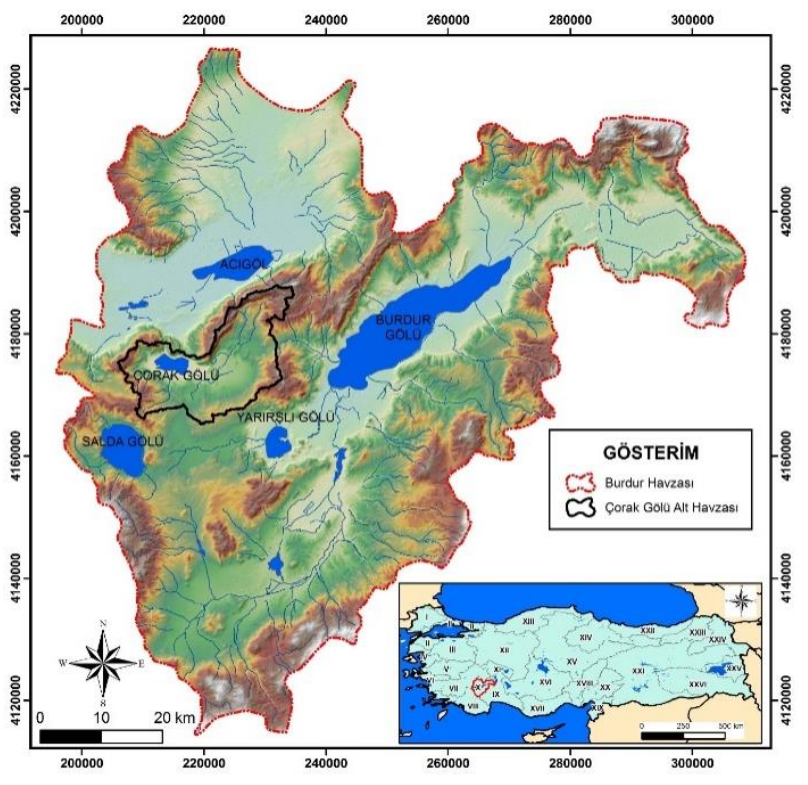

Şekil 1. Çalışma alanının yerbulduru haritası

Çorak Gölü sulak alanı ve yakın çevresinin hidrojeolojik incelemelerini kapsayan bu çalışma ile bölgenin jeolojik, hidrolojik ve hidrojeolojik özelliklerinin yanısıra yeraltısuyu seviyesi ve dinamiği ile birlikte suların kalite özellikleri belirlenmiştir. Çalışma alanının stratigrafik ve yapısal özelliklerinin belirlenmesi için öncelikle ayrıntılı literatür incelemesi yapılarak bölgede daha önce yapılmış çalışmalar incelenmiștir. Elde edilen bilgiler arazi gözlemleri ile birleștirilerek çalışma alanının 1/50.000 ölçekli jeoloji haritası oluşturulmuştur.

Havza içerisinde ve çevresinde yeralan meteorolojik istasyonların uzun yıllara ait aylık/yıllık yağış ve sıcaklık verileri değerlendirilerek havzanın yağış ve sıcaklık analizleri yapılmıştır. Ayrıca, havzaya ait gerçek ve potansiyel buharlaşma-terleme değerleri "Thornthwaite" yöntemi ile belirlenmiştir. Jeolojik çalıșmalarla belirlenen litolojik birimlerin hidrojeolojik özellikleri dikkate alınarak çalışma alanının hidrojeoloji haritası hazırlanmıștır. Bölgenin yeraltısuyu dinamiğini ortaya koymak amacıyla yağışlı ve kurak dönemleri temsil edecek şekilde Haziran (2017) ve Eylül (2017) dönemlerinde yeraltısuyu seviye ölçümleri yapılmıştır. Elde edilen veriler kullanılarak havzanın yeraltısuyu seviye haritası hazırlanmıș ve yeraltısuyu akım yönü ile hidrolik eğim değerleri belirlenmiștir. Çorak Gölü havzasında su kalitesi çalışmaları kapsamında gölün su tuttuğu ve kurak olduğu zamanlarda yapılan su kalitesi izleme çalışmalarına ek olarak geçmiş yıllarda yapılan su analizleri sonuçları da değerlendirilmiştir. Haziran2017döneminde kaynak sularından su örneği alınarak katyon ve ağır metal analizleri yaptırılmıştır. Sıcaklık, elektriksel iletkenlik (EC), toplam çözünmüş katı 
madde (TDS) ve hidrojen iyonu konsantrasyonu ( $\mathrm{pH})$ değerleri ise Elmetron CX-401 ve YSI Professional Plus marka çok parametreli portatif su kalitesi ölçüm cihazı kullanılarak yerinde ölçümler ile belirlenmiştir.

\section{Araştırma Bulguları}

\subsection{Genel Jeoloji}

Çalışma alanında allokton konumlu kaya birimlerini, Bodrum Napı içerisinde ayırtlanan Akgöl grubuna ait Kayaköy dolomiti, Yandağ kireçtaşı ve çört üyesi ile Karaböğürtlen formasyonu; Marmaris Ofiyolit Napı'na ait Kızılcadağ melanj ve olistostromu ve Marmaris peridotiti;ile Domuzdağ Napı'na ait Dutdere kireçtaşları oluşturmaktadır. Bu birimler üzerinde neootokton konumlu Çameli formasyonu ile Alüvyon ve Yamaç molozu birimleri yer almaktadır (Şekil 2). Likya Naplarının alt ünitelerinde biri olan Bodrum Napı, Alt-Orta Triyas döneminde zaman zaman karasal, genelde sığ şelf, (Orta?-) Üst Triyas-Liyas (bazen Üst Triyas-Malm)'ta platform, Üst Liyas-Üst Kretase (bazen Kretase) döneminde pasif kıta kenarını temsil eden kaya birimlerinden oluşmaktadır (Çakmakoğlu, 2007). Bodrum Napı Ören grubu (Konak vd.,1987) ve Akgöl grubu (Bölükbaşı, 1987) ile temsil edilmektedir. Çalışma alanında Akgöl grubuna ait alttan üste doğru Üst Triyas-Liyas yaşlı Kayaköy dolomiti, Üst Kretase-Liyas yaşlı Yandağ kireçtaşı ve çört üyesi ile Senoniyen yaşlı Karaböğürtlen formasyonu bulunmaktadır.

Kayaköy Dolomiti (TRjk) dolomit ve dolomitik rekristalize kireçtaşlarından oluşmaktadır ve çalışma alanında Çorak Gölü'nün kuzeyinde çok dar bir alanda gözlenmektedir. Formasyonun egemen kaya türlerini gri, açık/koyu gri ve siyah renklerde, kalın-orta tabakalı, orta-ince kristalli, erime boşluklu rekristalize kireçtaşları ve dolomitler oluşturmaktadır. Yaklaşık 15-40 cm'lik eklem açıklıklarında kalsit dolguları gözlenmektedir (Şentürk, 2003). Formasyon en fazla $300 \mathrm{~m}$ kalınlığındadır. İçerisinde fosil bulgusuna rastlanamayan birimin yaşı stratigrafik ilişkileri dikkate alınarak deneştirimsel olarak Orta-Geç TriyasOrta Liyas olarak öngörülmüştür. Birim sığ karbonat şelf ortamında çökelmiştir (Şenel, 1997).

Yandağ kireçtaşı (JKya)Bilgin vd., (1990) tarafından adlandırılmış olup çört seviyeli kireçtaşlarından oluşmaktadır. Formasyon tabanda pembemsi gri renkli, kalın orta tabakalı bol brachiopod ve ammonit izli kireçtaşları ile başlar. Bu seviye üzerinde orta kalın tabakalı, gri, koyu gri, kirli beyaz renkli kireçtaşı ve dolomitik kireçtaşları yer almaktadır. Daha üstte inceorta-kalın tabakalı, gri bej, krem, koyu gri renkli mikritik dokulu üste doğru çört yumrulu kireçtaşları gözlenmektedir. Birimin en üst seviyelerinde kızll renkli çört seviyeleri izlenmektedir (Şenel, 1997). Çört Üyesi (JKyar) ince-orta tabakalı, kızıl, kızıl kahve, mor ve mavimsi renklerde radyolarit, çört ve şeyllerden oluşmaktadır. Çalışma alanında gölün kuzeybatısında yüzeylenmektedir. Çört üyesinin yaşı Geç Kretase olarak verilmektedir (Şenel, 1997). Yandağ kireçtaşları Kayaköy dolomitinin üzerine uyumlu olarak gelmektedir. Üstteki Karaböğürtlen formasyonu ile ise olası uyumsuz olarak örtülmektedir. Biriminyaşı Üst Liyas-Koniasiyen olarak kabul edilmiştir (Şenel 1997).

Karabögürtlen Formasyonu (Kka)kırıntılı kayaçlar ile birlikte yer yer bloklu flişle temsil edilmektedir. Birim ince-orta-kalın tabakalı gri, siyahımsı gri, yeşilimsi gri, siyah, açık kahve, kirli sarı vb. renklerde kumtaşı, kiltaşı ve silttaşlarından oluşmaktadır(Şenel, 1997, Şentürk, 2003). Formasyon tabanda Yandağ kireçtaşları ile tedrici geçişlidir. Yaklaşık $150 \mathrm{~m}$ kalınlık sunan birimin üst ilişkisi ise tektoniktir. İçerisinde genelde fosil bulundurmayan birimin yaşı kireçtaşı seviyelerinde saptanan fosil formlarına göre Üst Senoniyen yaşlı kabul edilmektir. Birim duraysız havza ortamında çökelmiştir (Şenel 1997).Marmaris ofiyolit napı yapısal olarak Bodrum napını oluşturan birimler üzerinde, Domuzdağ napının ise altında bulunmaktadır. Çalışma alanında Marmaris ofiyolit napı Marmaris peridoditi ve Kızılcadă melanj ve olistostromu ile temsil edilmektedir.

Marmaris Peridotiti (Kmo) ultramafik kayaçlardan oluşmakta olup Çapan (1980) tarafından adlandırılmıştır. Birim genel olarak yer yer serpantinleşmiş ultramafik kayaçlardan oluşmaktadır. Yaygın olarak izlenen harzburjitlerin aşınma yüzeyleri kızıl, kızıl kahve, yeșilimsi gri, kırılma yüzeyleri siyahımsı yeşil, yeşilimsi gri, koyu gri ve koyu yeşil renklerdedir. Yer yer serpantinitleşme sonucu parlaklığını kaybeden olivinler mat görünümlüdür. Serpantinitler tektonik hatlarda daha belirgin olup geniş yayılım göstermektedirler. Birim içerisinde makaslamaya uğramış gabro, diyabaz, piroksenit vb. kaya türleri sıklıkla görülmektedir (Şenel 1997). Marmaris peridotitinin alt ve üst ilişkisi tektonik olup kalınlığı 0-1000 m arasında değişmektedir. Birimin oluşum yaşı K-Ar yaş tayinine göre Apsiyen-Albiyen (Alt Kretase) olarak belirlenmiştir (Thuizat vd., 1981). Birimin kitasal kabuk üzerine bindirmesi Üst Senoniyen'de gerçekleşmiştir (Şenel 1997). 


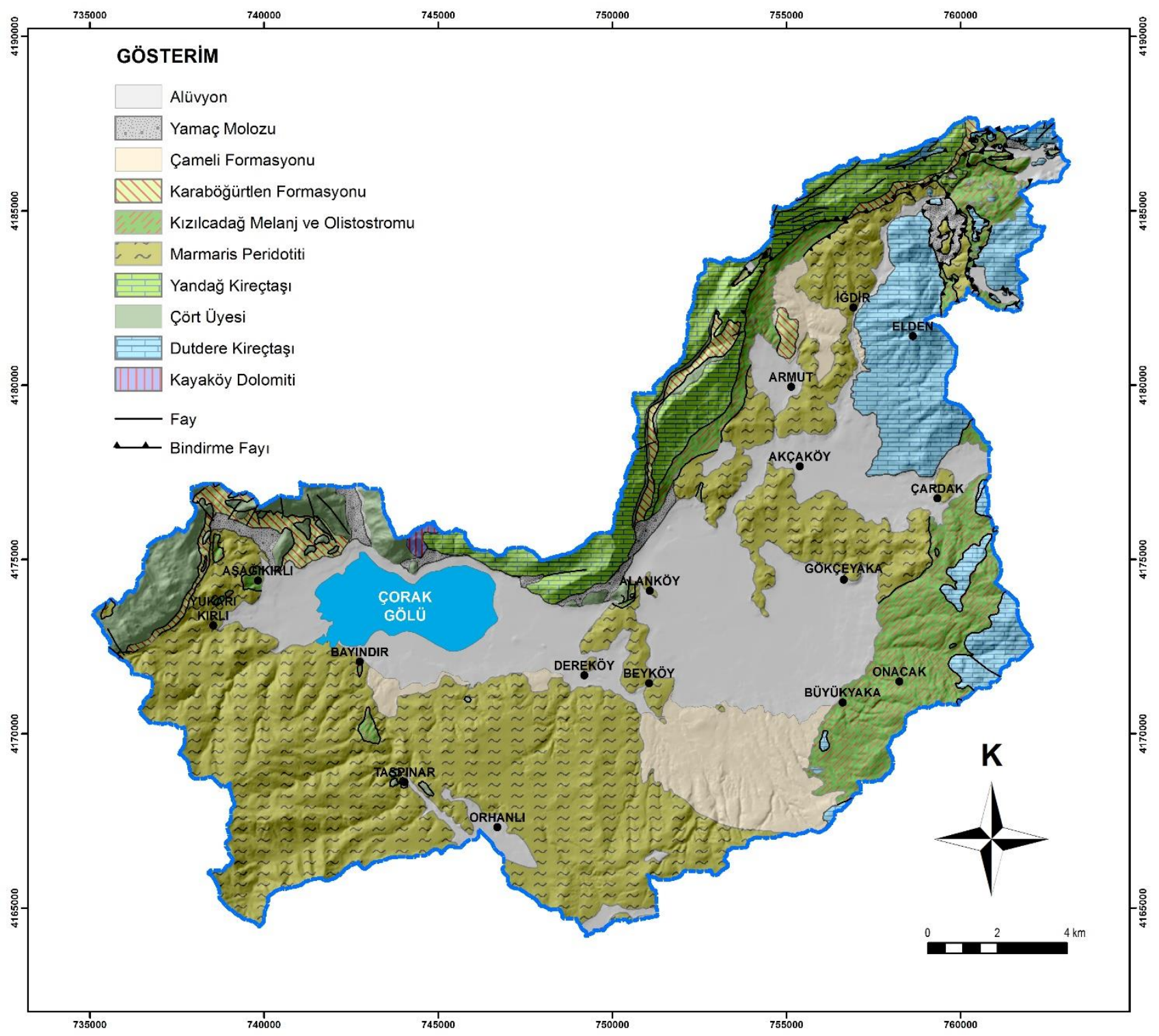

Şekil 2. Çalışma alanının genel jeoloji haritası

Kızılcadağ Melanj ve Olistostromu (Kkzm) ofiyolitli melanj ve olistostromla temsil edilmekte olup Poisson (1977) tarafından adlandırılmıştır. Birimi oluşturan ofiyolitik bloklar egemen olarak kireçtaşı, diyabaz, serpantinint, peridotit, gabro, radyolarit ve çört bileșenleri içermektedir. Ofiyolitler çoğunlukla türbiditlerden olușan bir matriks içerisinde düzensiz biçimde dağılmış olarak bulunur(Şentürk, 2003). Birimin alt ve üst dokanağı tektoniktir. Bölükbaşı (1987) tarafından yapılan çalışmada, jeolojik ve jeofizik verilere dayanarak birimin 1500 metre kalınlığa kadar ulaştığını vurgulamaktadır. Kızılcadağ ofiyolitli melanjının yaşı Sarp (1976), Poisson (1977) tarafından Üst Senoniyen olarak belirtilmiştir.

Likya Naplarının en üst birimi olan Domuzdağ Napı Orta Triyas-Liyas yaşlı Dutdere kireçtaşları ile temsil edilmektedir. Dutdere kireçtaşı (TRJd) yersel megaladonlu, rekristalize kireçtaşlarından oluşmaktadır ve Ersoy $(1989,1990)$ tarafindan adlandırılmıştır. Birim orta-kalın tabakalı, yersel masif, așınma yüzeyleri gri, kırılma yüzeyi beyaz, kirli beyaz, krem, bej ve gri renklerde, yer yer megalodonlu veya algli rekristalize kireçtaşlarından oluşmaktadır. Birimin üst düzeylerinde orta-kalın tabakalı gri, krem renkli kireçtaşları bulunur. Bunların üzerinde de pembe-kırmızı renkli, yersel çörtlü, ammonitli yumrulu kireçtașları yeralır (Şenel, 1997; Șentürk, 2003).Birim, Kızılcadağ ofiyolitli melanjı üzerine tektonik olarak gelmektedir. Yaklaşık 700 m kalınlık sunan birimin üst ilişkisi çalışma alanında izlenmemektedir. Sıkça Megalodon sp. içeren formasyon, Orta Triyas-Liyas yaşlıdır ve birim sı̆̆ karbonat şelfi ortamında çökelmiştir (Şenel, 1997).

Çameli Formasyonu (Plç) Erakman vd., (1982) tarafindan adlandırılmış olup genel olarak kumtaşı, marn, kiltaşı, konglomera gibi kaya türlerinden oluşmaktadır. Acıgöl güneyinde formasyon, alüvyon yelpaze çökellerini kontrol eden konglomera, kumtaşı ve çamurtaşı ile gölsel karakterde kumtaşı, silttaşı, 
kiltaşı, marn, killi kireçtaşı ve konglomeraları kapsar. Alüvyon yelpazesi şeklinde görülen formasyon (İğdir köyü güneybatısı, Armut Köyü kuzeyi), çökeldikleri yer ve konuma göre değişik oranlarda çakıltaşı, kumtaşı ve çamurtaşlarından oluşur. Bu birimler ardalanma gösterdikleri gibi yanal yönde birbirleri ile griftirler (Şentürk, 2003). Çameli formasyonu, kendisinden yaşlı birimler üzerine uyumsuz olarak yerleşmiştir. Üstte de Kuvaterner birimler tarafindan diskordans olarak örtülür. Birimin yaşı Göktaş vd. (1989)'ne göre Pliyosen'dir.

Yamaç Molozu (Qym)temel kayalardan iç ve dış kuvvetlerin etkisiyle ayrılan kil, silt, kum, çakıl ve blok boyutundaki malzemelerin gevşek yığışımından oluşmuştur. Birim, Kuvaterner yaşlı olup alüvyon ile yanal geçiş sunar. Alüvyon (Qal)genel olarak ovada, dere yataklarında ve yer yer sırtlardaki düzlüklerde gözlenmektedir. Çevredeki kaya birimlerinden türeyen birim gevşek tutturulmuş kil, silt, kum, çakıl ve blok boyutundaki tortullar ve bunların ardalanmasından meydana gelmiştir. Kendisinden yaşlı olan tüm kaya birimlerini uyumsuz olarak örten birimin yaş tayini stratigrafik konumlarına göre Kuvaterner olarak belirlenmiştir.

\subsection{Hidroloji}

\section{Yağış Analizi}

Çalışma alanının yağış analizinin yapılabilmesi için seçilen altı adet meteoroloji istasyonuna (Denizli, Dinar, Burdur, Tefenni, Korkuteli ve Acıpayam) ait aylık toplam yağış ve yıllık yağış verileri ayrıntılı olarak incelenmiştir. Söz konusu yağış verileri kullanılarak havzaya ait aylık ve yıllık ortalama yağış dağılım haritaları hazırlanmış ve havzanın genel yağış durumu değerlendirilmiştir.

Çorak Gölü havzası için yukarıda bahsedilen meteoroloji istasyonlarının yıllık ortalama yağış miktarları $359.8 \mathrm{~mm}$ ile $559.2 \mathrm{~mm}$ arasında değișmektedir. Aylık ortalama yağıș miktarları ise 30 $\mathrm{mm}$ ile $46.6 \mathrm{~mm}$ arasındadır. Havzaya ait ortalama toplam yıllık yağış dağılım haritası meteoroloji istasyonlarında ölçülen ortalama yıllık toplam yağış değerleri kullanılarak ArcGIS yazılımında IDW (Inverse Distance Weighted) interpolasyon yöntemi ile hazırlanmıştır (Şekil 3). Buna göre havzaya düşen maksimum yağış miktarı $443.91 \mathrm{~mm}$, minimum yağış miktarı ise $410.4 \mathrm{~mm}$ olarak belirlenmiştir. Genel olarak havzanın batısında maksimum yağışlar gözlenirken havzanın doğu kesimleri nispeten daha düşük miktarlarda yağış almaktadır.

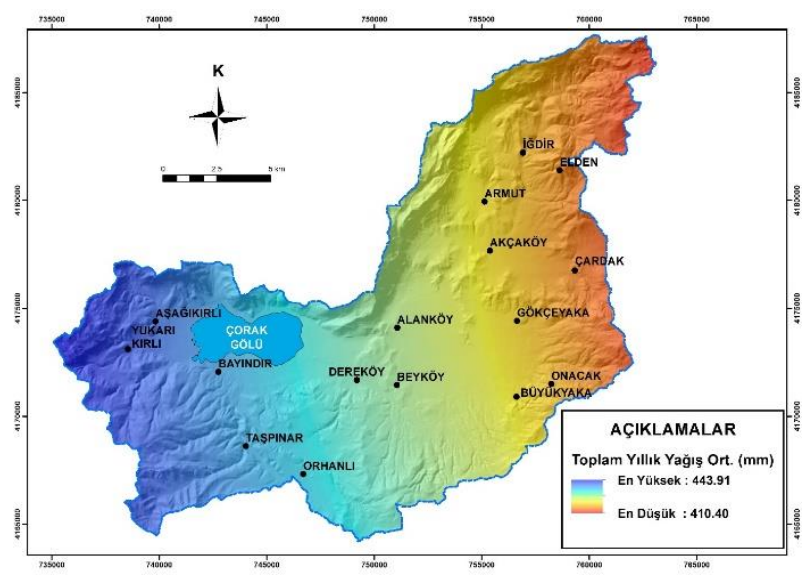

Şekil 3. Çorak Gölü havzasına ait ortalama toplam yıllık yağış dağılım haritası

\section{Sicaklık Analizi}

Havzada seçilen altı adet meteoroloji istasyonunda aylık ortalama sıcaklık değerleri $11.8{ }^{\circ} \mathrm{C}$ ile $16.2{ }^{\circ} \mathrm{C}$ arasında değişmektedir.Havzada ölçülen maksimum sıcaklık değeri $13.13{ }^{\circ} \mathrm{C}$ minimum sıcaklık değeri ise $12.73{ }^{\circ} \mathrm{C}$ olarak belirlenmiştir. Genel olarak havzanın kuzeyinde maksimum sıcaklık değerleri gözlenirken havzanın güney kesimleri nispeten daha düșük sıcaklığa sahiptir. Meteoroloji istasyonlarında ölçülen ortalama yıllık sıcaklık değerleri kullanılarak ArcGIS yazılımında IDW (Inverse Distance Weighted) interpolasyon yöntemi ile hazırlanmış olan ortalama sıcaklık dağılım haritası Şekil 4'de sunulmuştur.

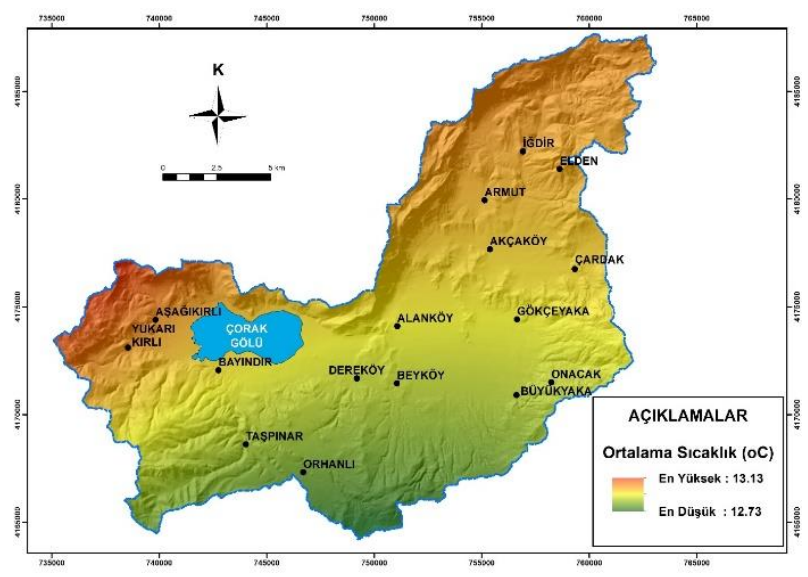

Şekil 4. Çorak Gölü havzasına ait ortalama sıcaklık dağılım haritası

\section{Buharlaşma Analizi}

Çorak Gölü havzasında yeralan ve açı yüzey buharlaşma ölçümleri yapılmış olan Denizli, Burdur, Korkuteli ve Acıpayam meteoroloji istasyonlarında yıllık ortalama buharlașma miktarları en düşük $1135.2 \mathrm{~mm}$ (Denizli DMİ), en yüksek ise $1225.6 \mathrm{~mm}$ (Acıpayam DMI)'dir (Tablo 1). İncelenen meteoroloji istasyonlarının verilerine göre aylık ortalama buharlaşma değerleri ise $143.3 \mathrm{~mm}$ (Denizli DMİ) ile 
175.8 mm (Acıpayam DMİ) arasında değişmektedir. İstasyonlarda ölçülen en yüksek aylık buharlaşma değerleri Temmuz ayında ölçülmüştür.

Tablo 1. Meteoroloji İstasyonlarında ölçülen buharlaşma değerleri

\begin{tabular}{|l|c|c|}
\hline $\begin{array}{l}\text { Meteoroloji } \\
\text { İstasyonları }\end{array}$ & $\begin{array}{c}\text { Yıllık ortalama } \\
\text { buharlaşma (mm) }\end{array}$ & $\begin{array}{c}\text { Aylık ortalama } \\
\text { buharlaşma (mm) }\end{array}$ \\
\hline Denizli DMİ & 1135.2 & 143.3 \\
\hline Burdur DMI & 1197.8 & 165.2 \\
\hline Korkuteli DMİ & 1167.6 & 166.8 \\
\hline Acıpayam DMI & 1225.6 & 175.8 \\
\hline
\end{tabular}

Ayrıca, Çorak Gölü havzasına ait gerçek ve potansiyel buharlaşma-terleme değerleri "Thornthwaite" yöntemi ile belirlenmiştir. Thornthwaite yönteminin uygulamasında havzayı en iyi şekilde temsil edecek olan Denizli, Burdur, Dinar ve Tefenni meteoroloji istasyonlarında uzun yıllar boyunca ölçülen aylık yağış ve sıcaklık değerlerinin ortalamaları ile, bölgenin bulunduğu enleme ait düzeltme katsayıları kullanılmıștır.

Söz konusu meteoroloji istasyonları için 1970-2016 yılları arasındaki aylık potansiyel buharlaşma-terleme (Etp) ve gerçek buharlaşma-terleme (Eta) miktarları hesaplanmış ve Tablo 2'de verilmiştir. Aylık değerlerin toplamiyla elde edilen yllık potansiyel buharlaşma-terleme (Etp) miktarları Burdur DMİ için $735.5 \mathrm{~mm}$, Tefenni DMİ için $687.74 \mathrm{~mm}$, Dinar DMİ için $746.8 \mathrm{~mm}$, Denizli DMİ için ise $865.6 \mathrm{~mm}$ olarak belirlenmiştir. Yıllık gerçek buharlaşma-terleme (Eta) miktarları ise Burdur DMİ için $347.5 \mathrm{~mm}$, Tefenni DMİ için 339.08 mm, Dinar DMİ için 382.8 mm, Denizli DMİ için ise $386.1 \mathrm{~mm}$ 'dir.

Tablo 2. Thornthwaite yöntemi ile hesaplanan aylık gerçek ve potansiyel buharlaşma-terleme değerleri

\begin{tabular}{|c|c|r|r|r|r|r|r|r|r|r|r|r|r|}
\hline $\begin{array}{c}\text { Meteoroloji } \\
\text { Istasyonları }\end{array}$ & & Ocak & Subat & Mart & Nisan & Mayıs & Haziran & Temmuz & Ağustos & Eylül & Ekim & Kasım & Aralk \\
\hline \multirow{2}{*}{ Burdur DMi } & Etp & 4,09 & 6,99 & 21 & 44,8 & 81,6 & 117,34 & 147,62 & 136,6 & 92,6 & 53,6 & 21,7 & 7,17 \\
\cline { 2 - 16 } & Eta & 4,09 & 6,99 & 21 & 44,8 & 81,6 & 83,1 & 15,4 & 9,2 & 16,9 & 35,2 & 21,7 & 7,17 \\
\hline \multirow{2}{*}{ Tefenni DMi } & Etp & 2,04 & 4,65 & 19 & 43,3 & 78,7 & 110,45 & 138,19 & 127,88 & 87,2 & 51,1 & 19,6 & 5,13 \\
\cline { 2 - 15 } & Eta & 2,04 & 4,65 & 19 & 43,3 & 78,7 & 85,08 & 17,9 & 14,3 & 14,9 & 34 & 19,6 & 5,13 \\
\hline \multirow{2}{*}{ Dinar DMi } & Etp & 5,3 & 7,9 & 22 & 45,9 & 82 & 117,4 & 148,8 & 138,4 & 92,4 & 54 & 23,5 & 9,2 \\
\cline { 2 - 13 } & Eta & 5,3 & 7,9 & 22 & 45,9 & 82 & 99,4 & 18 & 15,8 & 17,9 & 35,9 & 23,5 & 9,2 \\
\hline \multirow{2}{*}{ Denizli DMi } & Etp & 8,7 & 11,4 & 27 & 52,2 & 95,6 & 139,8 & 173 & 157,9 & 103 & 59,7 & 26,1 & 11,8 \\
\cline { 2 - 12 } & Eta & 8,7 & 11,4 & 27 & 52,2 & 95,6 & 71 & 18,4 & 11,6 & 14,8 & 37,9 & 26,1 & 11,8 \\
\hline
\end{tabular}

\subsection{Hidrojeoloji}

\section{Su Noktaları}

Çorak Gölü, ülkemizin güneybatısında bulunan Göller Bölgesi içerisinde ve Burdur Gölleri Havzası sinırları dâhilinde yer alan küçük göllerinden birisidir. Yaklaşık $9.98 \mathrm{~km}^{2}$ lik bir yüzey alanına sahip olan Çorak Gölü kapalı havza özelliğinde olup havza dıșına akış vermez ve de havza dışından herhangi bir akış almamaktadır. Hidrolojik su bütçesini oluşturan en önemli unsurlar gölün beslenim ve boşalım elemanlarıdır. Gölün beslenimi; göl aynasına ve alt havza geneline düşen yağışlar, sürekli ve/veya mevsimsel akarsular ve kaynak sularıdır. Ancak havzada dere ve kaynak suları göle ulaşamadan kurumaktadır. Gölün boşalımı ise yalnızca buharlaşma ile gerçekleșmektedir. Kapalı bir havza olan Çorak Gölü alt havzasında Şabanözü deresi, İğdecik deresi ve Dibekçukuru deresi ve mevsimsel dereler bulunmaktadır. Ayrıca, farklı lokasyonlarda boşalım gösteren irili ufaklı soğuk su kaynak çıkışı bulunmaktadır.

Çorak Gölü havzası içerisine bulunan ve DSİ 18. Bölge Müdürlüğü tarafından Aşağıkırlı, Bayındır ve Dereköy köyleri civarında açılmış olan sondaj kuyularına ait loglar Şekil 5'de verilmiştir. Sondaj loglarının derinliği $68 \mathrm{~m}$ ile $112 \mathrm{~m}$ arasında değişmektedir. Dereköy civarında açlmış olan 26961 nolu sondajda ilk 20 m'den sonra serpantin birimine girilmektedir. Aşağıkırlı köyü civarında açılmış olan 47974 nolu sondajda ilk $75 \mathrm{~m}$ çakıl, kil ve çakıllı kil birimlerinin ardalanması görülmekte ve sonrasında serpantin birimi kesilmektedir. Bayındır köyü civarında açılmış olan 45895 nolu sondajda da ilk $90 \mathrm{~m}$ çakıl, killi çakıl ve çakıllı kil ardalanması, devamında serpantin birimi izlenmiştir.

\section{Litolojik Birimlerin Hidrojeolojik Özellikleri}

Çorak Gölü havzasında bulunan litolojik birimler, hidrojeolojik özelliklerine göre tekrar değerlendirilerek sinıflandırılmış ve bölgenin hidrojeoloji haritası hazırlanmıștır (Şekil 6). Havzada yer alan jeolojik birimler fiziksel ve hidrojeolojik özellikleri ile akifer olabilme potansiyelleri bakımından Yaygın verimli akifer, erimeli çatlaklı kaya ortam akiferi, yarı geçirimli birim ve geçirimsiz birim olmak üzere dört ayrı grupta incelenmiștir. Çalışma alanında yüzeyleyen söz konusu hidrojeolojik birimler aşağıda ayrıntılı olarak açıklanmıştır.

Yaygın verimli Akifer: Çalışma alanında, ovanın büyük bir kısmını oluşturan alüvyon ile konglomera ve kaba kırıntılardan oluşan yamaç molozu yayılımı ve verimi fazla olan yaygın verimli akiferi temsil etmektedir. Alüvyon birimi genel olarak değişik boyutlarda çakıllar içeren, geniş düzlüklerde ince tane oranı artan bir yapı ortaya koymaktadır. Yaygın verimli akiferin ova genelindeki yayılımı $74.3 \mathrm{~km}^{2}$ 'dir.

Erimeli Çatlaklı Kaya Ortam Akiferi: Çalışma alanında yüzeyleyen Yandağ kireçtaşları, Dutdere kireçtaşı ve Kovada dolomiti Erimeli Çatlaklı Kaya Ortam Akiferini temsil etmektedir. Karstik birimler yapısındaki erime boşlukları ve kırık-çatlak sistemleri nedeniyle bünyelerinde önemli ölçüde yeraltısuyu bulundurabilen ve iletebilen bir özelliğe sahiptirler. Çalışma alanında ovanın kuzey, kuzeydoğu ve doğu sinırlarında yayılım gösteren akifer birim alüvyonun altında yaklaşık 10-15 m kalınlığında kesilmiştir.

Yarı Geçirimli Birim: Çalışma alanında yüzeyleyen Çameli formasyonu ve Karabögürtlen formasyonu 
bünyelerinde yeraltısuyu bulundurma özellikleri bakımından benzer hidrojeolojik yapıya sahip olduklarından tek bir hidrojeolojik birim olarak kabul edilmiştir. Birimler içerdikleri kumtaşı, konglomera, ve kireçtaşı seviyeleri ve yayılım - kalınlıkları ile doğru orantılı olarak yeraltısuyu içerebilmektedirler. Bu nedenle sözkonusu birimler düşük hidrolik iletkenliğe sahip hidrojeolojik olarak yarı geçirimli birimler olarak sınıflandırılmıştır.

Geçirimsiz Birim: Çalışma alanında su iletme yeteneği olmayan ve geçirimsiz özelliğe sahip Kızılcadağ Melanj ve Olistostromu, Marmaris peridotiti, Çört üyesi geçirimsiz birimler olarak tanımlanmıştır. Kızılcadağ Melanjı başlıca radyolarit, mafik-ultramafik kayaçlar, şist ve kireçtaşı blokları, yer yer kumtaşı-grovak-şeyl, kumlu kalker, şist, tüfit ve konglomera birimlerinden oluşan bir karmaşık özelliği sunmaktadır. Marmaris peridotiti ise yer yer serpantinleşmiş ultramafik kayaçlardan oluşmaktadır. Sözkonusu birimlerin litolojik özellikleri bakımından akifer olma potansiyeli olmaması sebebiyle geçirimsiz birim olarak değerlendirilmiştir.

\section{Yeraltısuyu Dinamiği}

Çorak gölü havzası içerisinde yeraltısuyu dinamiğini ortaya koymak amacıyla yağışlı ve kurak dönemleri temsil edecek şekilde Haziran (2017) ve Eylül (2017) dönemlerinde yeraltısuyu seviye ölçümleri yapılmıştır. Ölçüm yapılan sondaj kuyularının hepsi alüvyon ortamda olup bölgede yeraltısuyu derinlikleri yağışlı dönemde $2.2 \mathrm{~m}$ ile $35.2 \mathrm{~m}$ arasında; kurak dönemde ise $2.7 \mathrm{~m}$ ile $36.1 \mathrm{~m}$ arasında değişmektedir. Yeraltısuyunun deniz seviyesinden yükseklikleri ise yağışlı dönemde $995.3 \mathrm{~m}$ ile $1136.85 \mathrm{~m}$ arasında, kurak dönemde ise 994.9 m ile 1134.8 m arasındadır.
Havza için hazırlanan yeraltısuyu seviye haritalarına göre yağışlı ve kurak dönemde yeraltısuyu seviye dağılımları arasında önemli bir fark yoktur. Seviye eğrileri genel olarak birbirine paralel ve gidişleri düzgündür. $\mathrm{Bu}$ durum akifer ortamın izotrop ve homojen olduğunu göstermektedir. Ayrıca, Çorak Gölü civarında yeraltısuyu seviye eğrileri sık, Gökçeyaka ve Alanköy civarında ise daha seyrektir. Yeraltısuyu seviye eğrilerinin sık olması akifer ortamın düşük permeabiliteye ve yüksek hidrolik eğime sahip olduğunu belirtmektedir. Bayındır civarında açılmış olan 45895 nolu sondaj kuyusunda akifer birim içerisinde bulunan killi seviyeler ortamın geçirimliliğini kısıtlamakta olup, eğrilerin sık gözlendiği bölgelerin düşük permeabiliteye sahip olduğunu desteklemektedir. Ayrıca bu bölgede hidrolik eğim değeri 0.014 olarak hesaplanmıştır. Buna karşın seviye eğrilerinin seyrek olması bölgelerde permeabilite değerinin yüksek, hidrolik eğimin ise düşük olduğunu göstermektedir. Gökçeyaka ve Alanköy civarında hesaplanan hidrolik eğim değeri ise 0.003 'tür. Bölgede yeraltısuyu akımı, ovanın doğusundan batı-güneybatıya doğru yani Çorak Gölü'ne doğrudur. Akçaköy ve Çardak civarında ise yeraltısuyu akım yönünün güney ve kısmen güneydoğuya doğru olduğu belirlenmiștir (Şekil 7).

\subsection{Su Kalitesi}

Göl aynasının tamamen kuruduğu dönemde Corak Gölü çevresinde daimi çıkışlı Sülüközü Pınarı, Dağ Pınarı çeşmesi, Etpınar Çeşmesi ve 1983 Pınarı Çeşmesinden su örnekleri alınmıştır. Su örneklerinin kimyasal analiz sonuçları Tablo 3'de sunulmuştur. Ayrıca, 2013 yılında, gölün su tuttuğu dönemde alınan göl suyu örneklerinin kimyasal analiz sonuçları değerlendirilmiștir (Tablo 4).

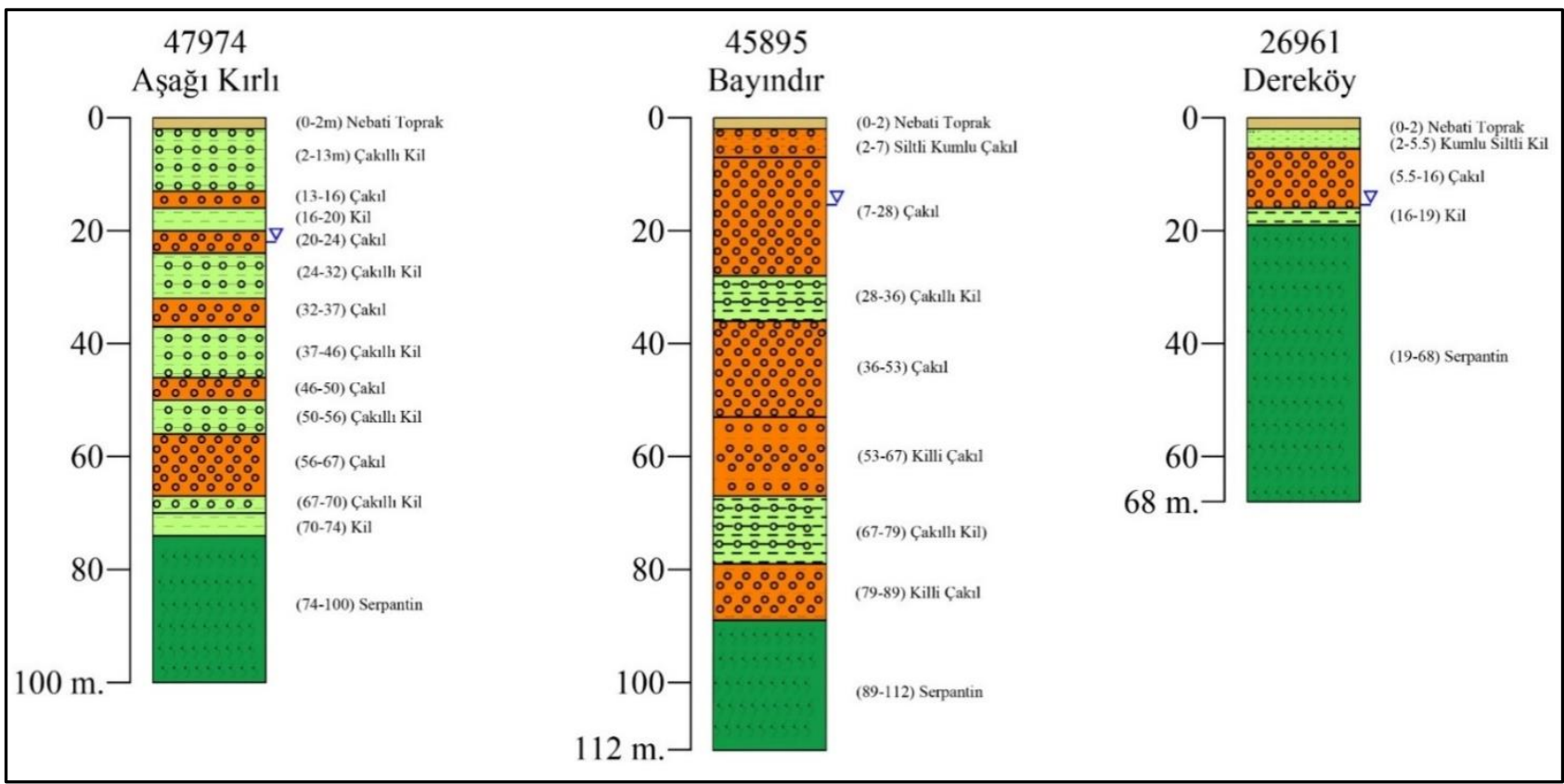

Şekil 5. Çorak gölü alt havzası içerisine bulunan 47974, 45895 ve 26961 nolu sondajlara ait loglar 


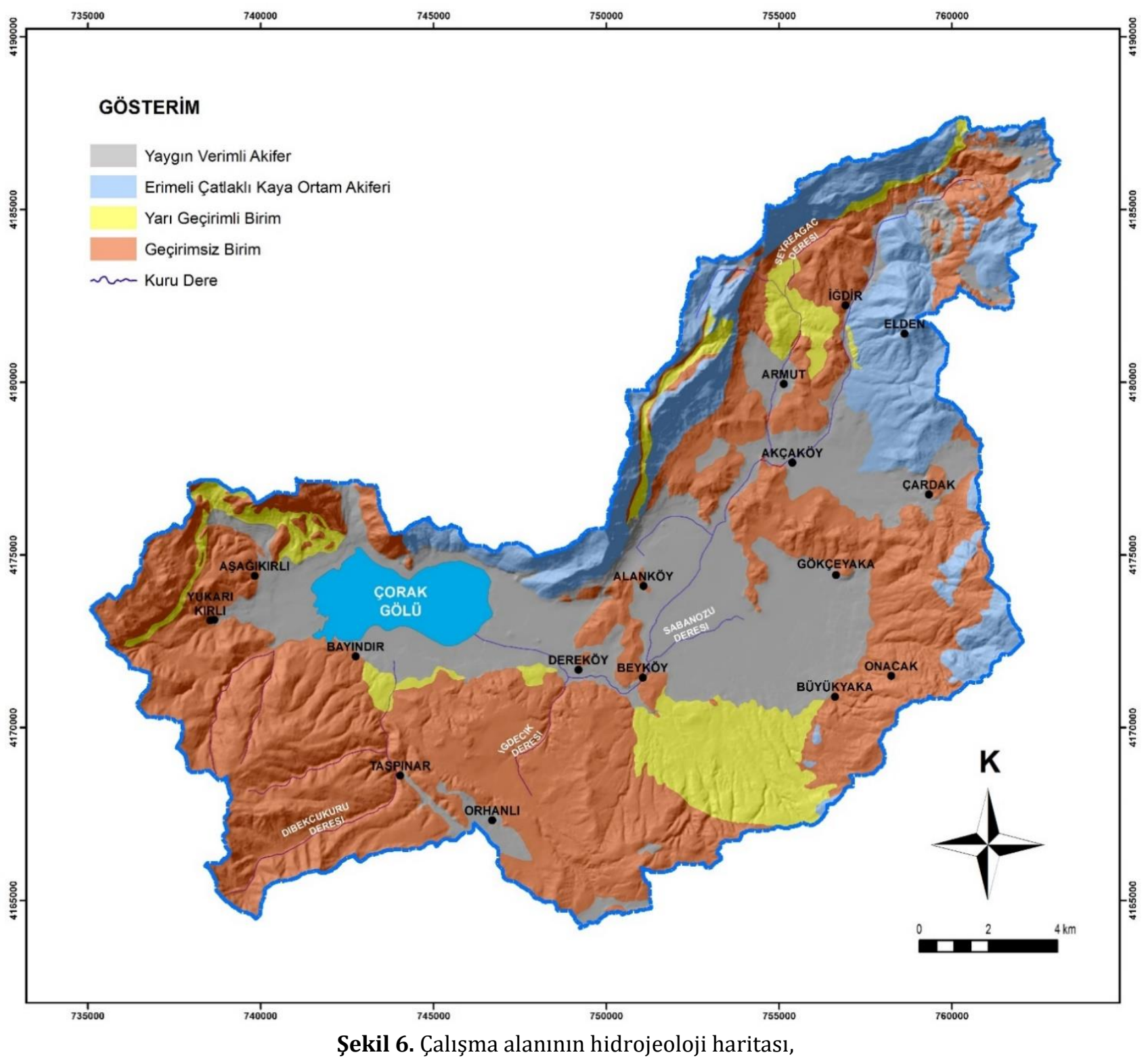




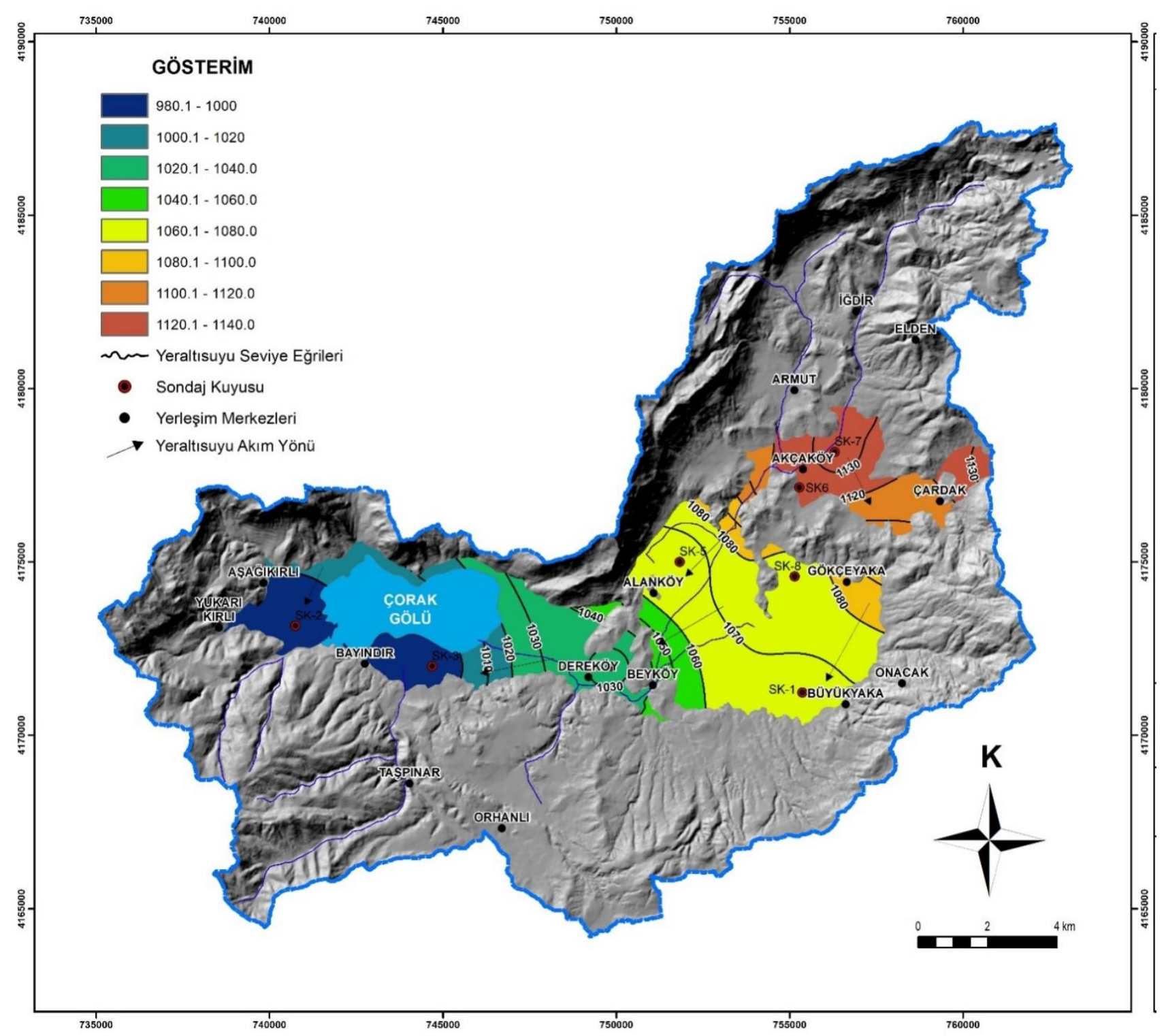

Şekil 7. Çorak Gölü Havzasının yeraltısuyu seviye haritası (Yağışlı dönem - Haziran, 2017) 
Tablo 3. Göl çevresindeki kaynak suyu örneklerinin kimyasal analiz sonuçları (Ekim-2017)

\begin{tabular}{|l|c|c|c|c|}
\hline Parametreler & $\begin{array}{c}\text { Sülüközü } \\
\text { Pınarı }\end{array}$ & Dăg Pınarı & Etpınar & 1983 Pınarı \\
\hline Koordinat & $742168:$ & $742087:$ & $743329:$ & $742720:$ \\
4172503 & 4174846 & 4172161 & 4171899 \\
\hline pH & 8,16 & 7,46 & 7,76 & 8,01 \\
\hline İletkenlik (4S/cm) & 781 & 906 & 901 & 839 \\
\hline Çözünmüş Oksijen (mg/L) & 5,6 & 6,93 & 7,07 & 7,44 \\
\hline Nitrat (mg/L) & 1,95 & 2,88 & 2,07 & 1,34 \\
\hline Sülfat (mg/L) & 11,7 & 17,3 & 13 & 12 \\
\hline Klorür (mg/L) & 22,5 & 16 & 12 & $<10$ \\
\hline Florür (mg/L) & 0,48 & 0,34 & 0,41 & 0,17 \\
\hline Krom VI (mg/L) & $<0,1$ & $<0,1$ & $<0,1$ & $<0,1$ \\
\hline Bor (mg/L) & $<1,0$ & $<1,0$ & $<1,0$ & $<1,0$ \\
\hline Alkalinite (Karbonat) (mg/L) & 27 & $<10$ & 24 & 35 \\
\hline Alkalinite (Bikarbonat) (mg/L) & 413 & 491 & 499 & 477 \\
\hline Kalsiyum (mg/L) & 5,487 & 76 & 30,5 & 4,35 \\
\hline Magnezyum (mg/L) & 113,7 & 81,9 & 119,1 & 132,8 \\
\hline Arsenik (mg/L) & $<0,0005$ & 0,0007 & $<0,0005$ & $<0,0005$ \\
\hline Bakır (mg/L) & $<0,001$ & $<0,001$ & $<0,001$ & $<0,001$ \\
\hline Demir (mg/L) & $<0,005$ & $<0,005$ & $<0,005$ & $<0,005$ \\
\hline Kurşun (mg/L) & $<0,0005$ & $<0,0005$ & $<0,0005$ & $<0,0005$ \\
\hline Çinko (mg/L) & $<0,005$ & $<0,005$ & $<0,005$ & 0,015 \\
\hline Civa (mg/L) & $<0,0001$ & $<0,0005$ & $<0,0001$ & $<0,0001$ \\
\hline Nikel (mg/L) & $<0,005$ & $<0,005$ & $<0,005$ & $<0,005$ \\
\hline Kadmiyum (mg/L) & $<0,02$ & $<0,02$ & $<0,02$ & $<0,02$ \\
\hline Alüminyum (mg/L) & $<0,0005$ & $<0,0005$ & $<0,0005$ \\
\hline
\end{tabular}

Çorak Gölü'nün fiziksel ve kimyasal özellikleri irdelendiğinde 1998 yılında gölün su tuttuğu, bundan önceki 3 yıl kuru olduğu belirtilmiştir (Kazancı vd., 1999). Üç yıl süren kuraklık sonrasında gölün ilk kez su tuttuğu dönemde yürütülen arazi çalışmalarına göre (27.05.1998) gölün maksimum derinliğini $35 \mathrm{~cm}$ olup Elektriksel İletkenliğin $750 \mu \mathrm{S} / \mathrm{cm}$, Çözünmüș oksijenin 8,2 mg/l, pH'nın 8,2 olduğu belirtilmektedir (Kazancı vd., 1999).

Tablo 4. Göl suyunun kimyasal analiz sonuçları (2013 yılı)

\begin{tabular}{|c|c|}
\hline Parametreler & Değerler (2013) \\
\hline Su Sıcaklığı $\left({ }^{\circ} \mathrm{C}\right)$ & 5 \\
\hline $\mathrm{pH}$ & 9,25 \\
\hline Elektriksel İletkenlik (25ㅇ'de $\mu \mathrm{S} / \mathrm{cm})$ & 1045 \\
\hline Bulanıklık (NTU) & 25 \\
\hline Renk (Pt/Co) & 1,45 \\
\hline Secchi Disk Derinliği (m) & 0,2 \\
\hline Çözünmüş $\mathrm{O}_{2 \cdot} \cdot(\mathrm{mg} / \mathrm{l})$ & 9,65 \\
\hline Çözünmüş $\mathrm{O}_{2}$.Doy. (\%) & 102 \\
\hline Nitrat-N (mg/l) & $<0.060$ \\
\hline Toplam Azot-N (mg/l) & 1,9 \\
\hline Toplam Fosfat -P (mg/l) & $<0,010$ \\
\hline Sülfat $(\mathrm{mg} / \mathrm{l})$ & 81,5 \\
\hline ToplamÇözünmüş Katı Madde (g/l) & - \\
\hline Sertlik $\left(\mathrm{CaCO}_{3} \mathrm{mg} / \mathrm{l}\right)$ & 1015 \\
\hline T. Amonyak-N (mg/l) & 0,124 \\
\hline Nitrit-N (mg/l) & $<0,0020$ \\
\hline İnorg. Azot-N (mg/l) & $<0,500$ \\
\hline Org. Azot $-\mathrm{N}(\mathrm{mg} / \mathrm{l})$ & 1,84 \\
\hline Kjelahl Azotu-N (mg/l) & 1,94 \\
\hline
\end{tabular}

Çalıșma alanındaki yüzey sularının kalite siniflandırılmasında $\mathrm{Su}$ Kirliliği Kontrol Yönetmeliği'nde (2008) belirlenen "Kıta İçi Su Kaynaklarının Sınıflarına Göre Kalite Kriterleri'ne ait limit değerler kullanılmıştır. Yapılan değerlendirmeye göre çalışma alanındaki yüzey ve kaynak sularının tamamının genel olarak I. su kalite sınıfında olduğu görülmektedir. Gerek 2013 yılında yapılan ayrıntılı su kalitesi analizleri, gerekse çalışma kapsamında (2017 yılında) yapılan analiz ve ölçümlerde, Çorak Gölü ve çevresinden çıkan kaynak sularında insan ve çevre sağlığını olumsuz etkileyecek herhangi bir parametreye rastlanılmamıştır.

Göl suyu kalitesini "Tatlısu” olarak değerlendirmek veya yönetmeliklerde belirtilen "Tatlısu kalite sınıflarıyla" karşılaştırmak doğru bir yaklaşım olmayacaktır. Göl suyu trofik düzey açısından mezotorfik seviye olarak değerlendirilebilir. Ancak, trofik sınıf (Carlson Indeksi) değerlendirmelerinde kullanılan klorofil-a ve Secchi diski derinliğinin yaz aylarında gölün kurumasından dolayı alınamaması uluslararası standartlarda bir trofik düzey sınıflandırmasının yapılmasını mümkün kılmamaktadır.

\section{Sonuçlar}

$\mathrm{Bu}$ çalışmada, Çorak Gölü havzasının hidrolojik ve hidrojeolojik incelemeleri yapılarak yeraltısuyu 
seviyesi ve dinamiği ile birlikte su kalite değerlendirmeleri yapılmıștır. Çorak Gölü kapalı havza özelliğinde olup havza dıșına akıș vermez ve havza dışından herhangi bir akış almamaktadır. Gölün beslenimi; göl aynasına ve alt havza geneline düşen yağışlar, sürekli ve/veya mevsimsel akarsular ile kaynak sularıdır. Gölün boşalımı ise yalnızca buharlașma ile gerçekleșmektedir. Sulak alanın beslenmesini sağlayan başlıca yüzey suları Şabanözü Deresi, İğdecik Deresi ve Dibekçukuru Deresi ve mevsimsel derelerdir. Ayrıca göl çevresinde düşük debili kaynak çıkışları gözlenmektedir.

Çorak Gölü havzasına düșen maksimum yağıș miktarı $443.91 \mathrm{~mm}$, minimum yağış miktarı ise $410.4 \mathrm{~mm}$ olarak belirlenmiştir. Havzada,aylık ortalama sıcaklık değerleri $11.8{ }^{\circ} \mathrm{Cile} 16.2^{\circ} \mathrm{C}$ arasındadır. Havzada ölçülen maksimum sıcaklık değeri $13.13{ }^{\circ} \mathrm{C}$ minimum sıcaklık değeri ise $12.73{ }^{\circ} \mathrm{C}$ olarak belirlenmiştir.Yıllık gerçek buharlaşma-terleme (Eta) miktarları ise Burdur DMİ için 347.5 mm, Tefenni DMİ için 339.08 $\mathrm{mm}$, Dinar DMİ için $382.8 \mathrm{~mm}$, Denizli DMİ için ise $386.1 \mathrm{~mm}$ 'dir.

Havza sınırları içerisinde allokton konumlu kaya birimlerini Bodrum Napı içerisinde ayırtlanan Akgöl grubuna ait Kayaköy dolomiti, Yandağ kireçtaşı ve çört üyesi ile Karaböğürtlen formasyonu; Marmaris Ofiyolit Napı'na ait Kızılcadağ melanj ve olistostromu ve Marmaris peridotiti; Domuzdağ Napı'na ait Dutdere kireçtaşları oluşturmaktadır. Bu birimler üzerinde neootokton konumlu Çameli formasyonu ile Alüvyon ve Yamaç molozu birimleri yer almaktadır.

Bölgede yüzeyleyen jeolojik birimler akifer olabilme potansiyellerine göre yaygın verimli akifer, erimeli çatlaklı kaya ortam akiferi, yarı geçirimli birim ve geçirimsiz birim olmak üzere dört ayrı grupta incelenmiştir.Çalışma alanında bulunan yeraltısuyu kuyularının tamamı ovada alüvyon birim üzerinde açılmıştır. Sondaj loglarının derinliği 68 m ile $112 \mathrm{~m}$ arasında değişmekte olup Dereköy civarında ilk 20 m'den sonra; Aşağıkırlı köyü civarında ilk 75 m'den sonra; Bayındır köyü civarında ise ilk 90 m'den sonra serpantin birimine girilmektedir. Bölgede yeraltısuyu derinlikleri yağışlı dönemde $2.2 \mathrm{~m}$ ile $35.2 \mathrm{~m}$ arasında; kurak dönemde ise $2.7 \mathrm{~m}$ ile $36.1 \mathrm{~m}$ arasında değişmektedir.Yeraltısuyu akımı, ovanın doğusundan batı-güneybatıya doğru yani Çorak Gölü'ne doğrudur. Akçaköy ve Çardak civarında ise yeraltısuyu akım yönünün güney ve kısmen güneydoğuya doğru olduğu belirlenmiştir. Su kalite incelemeleri sonucunda Çorak Gölü ve çevresinden çıkan kaynak sularında insan ve çevre sağlığını olumsuz etkileyecek herhangi bir parametreye rastlanılmamıştır.

\section{Teşekkür}

Bu çalışma, Orman ve Su İşleri Bakanlığı,6. Bölge Müdürlüğü, Burdur İl Şube Müdürlügü adına "Burdur İli Tescilli Sulak Alanları Yönetim Planı Hazırlanması
Ve Çorak Gölü Alt Havzası Biyolojik Çeşitlilik Araştırması Projesi İle Bu Alanlarla İlgili Kitapçık, Broşür ve Tanıtım Malzemeleri Hazırlanması Hizmet Alımı İși” kapsamında yapılmış olup yazarlar, projeyi finansal olarak destekleyen Orman ve $\mathrm{Su}$ İşleri Bakanlığı'na teșekkür ederler.

\section{Conflict of Interest / Çıkar Çatışması}

Yazarlar tarafından herhangi bir çıkar çatışması beyan edilmemiştir.

No conflict of interest was declared by the authors.

\section{Kaynaklar}

Bilgin, Z.R., Karaman, T., Öztürk, Z., Şen, A.M. ve Demirci, A.R., 1990. Yeşilova- Acıgöl civarının jeolojisi: MTA Rap.9429, Ankara(yayımlanmamış).

Bölükbaşı, A.S., 1987. Elmalı (Antalya)-Acıgöl-Burdur Gölü (Burdur)- Korkuteli(Antalya) arasında kalan Elmalı napları jeolojisi: TPAO Rap. No: 2415, 247s., Ankara (yayımlanmamış).

Çapan., U.,1980. Toros kușağı ofiyolit masiflerinin (Marmaris, Mersin, Pozantı, Pınarbaşı, Divriği) iç yapıları, petrolojisi ve petrokimyalarına yaklaşımlar. H.Ü. Yerbil Ens. Doktora tezi, 400 s.

Göktaş, F., Çakmakoğlu, A.,Tarı, E.,Sütçü, Y.F. ve Sarıkaya, H., 1989. Çivril Çardak arasının jeolojisi : MTA rap.No.8701, Ankara.

Erakman, B., Meşhur, M., Gül, M.A., Alkan, H., Öztaş, Y., Akpınar, M., 1982. Fethiye-Köyceğiz-TefenniElmalı-Kalkan arasında kalan alanın jeolojisi, Türkiye Altıncı Pet. Kong. Tebl. Nisan, 1982, Ankara, 23-31.

Ersoy, Ş., 1989. Fethiye(Muğla)-Gölhisar(Burdur) arasında Güneydağı ile Kelebekli dağı ve dolayının jeolojisi: İ.Ü. Fen. Bil. Ens. Doktora tezi, 246s.

Ersoy, S.., 1990. Dirmil (Burdur) ve güneyindeki tektonik ve neootokton birimin stratigrafisi ve ortamsal yorumu: Türkiye Jrol. Bült., 32,2,9-24.

Güney, B., 2014. Havza Yönetim Planları İçerisinde Sulak Alanların Yeri, Kuş ve Habitat Direktifleriyle Olan İlișkisi, Orman ve Su İșleri Bakanlığı, Su Yönetimi Genel Müdürlüğü, Uzmanlık Tezi, 184 s. Ankara.

Kazancı, N., Girgin, S., Dügel, M., Oğuzkurt, D., Mutlu, B., Dere, Ş., Barlas, M., Özçelik, M., 1999. Köyceğiz, Beyşehir, Eğirdir,Akşehir, Eber, Çorak, Kovada,Yarışlı, Bafa, Salda, Karataş, Çavuşçu Gölleri, Küçük ve Büyük Menderes Deltası, Güllük Sazlığı, Karamuk Bataklığı'nın Limnolojisi, Çevre 
kalitesi ve Biyolojik Çeşitliliği, Türkiye İç Su Araştırmaları Dizisi IV,372 s.

Ketin, T., 1966. Anadolu'nun tektonik birlikleri. M.T.A. Derg. no. 66, s . 20-34, Ankara

Kissel, C., Poisson, A., 1986. Etude paléomagnétique préliminaire des formations néogènes du bassin d'Antalya (Taurides occidentales, Turquie). Comptes Rendu del'Académie des Sciences, 302,10, 711-716.

Konak, N., Hepşen, N., Öztürk, E.M., Öztürk, Z., Çakmakoğlu, A., Göktaş, F., Sarıkaya, H., Armağan, F., Çatal, E. ve Serdaroğlu, M., 1987. Menderes Masifinin G-GD'sundaki Mesozoyik istiflerinin karşılaştırmalı stratigrafileri ve konumları; Türkiyr Jeol. Kurultayı-1987, Bildiri özleri. 5.

Piper, J.D. A., Gürsoy, H., Tatar, O., 2002. Palaeomagnetic evidence for the Gondwanian origin of the Taurides and rotation of the Isparta Angle, southern Turkey. Geology Journal, 37, 4, 317-336.

Poisson, A., 1977. Recherches geologiques dans les Taurides occidentales (Turguie): These Univ. Paris. Sud, Orsay, 795p.

Ramsar, 1971. Convention on Wetlands of International Importance Especially as Waterfowl Habitat, Ramsar, Iran.

Sarp, H., 1976. Etude Geologique petrographigue du cortege ophiolitique de la region situee au NortQuest de Yeşilova(Burdur-Turquie): These Univ. Geneve, 377p.

Şenel, M. 1997. 1/100.000 ölçekli Türkiye Jeoloji Haritaları, Isparta J11 paftası. MTA Genel Müdürlüğü, jeoloji Etütleri Dairesi yayını, Ankara.

Şentürk, M., 2003. Acıgöl ve Burdur Gölleri Arasındaki Bölgenin Sismotektonik Özellikleri, SDÜ Fen Bilimleri Enstitüsü, Jeoloji Müh. ABD, Yüksek lisans tezi, 96 s. Isparta

T.C. Resmi Gazete, 2008. Su Kirliliği ve Kontrol Yönetmeliği, 25687.

Thuizat, R., Whitechurch, H., Montigny, R. ve Juteau, T., 1981. K-Ar dating of some infra-ophiolitic metamorphic soles from the Eastern Mediterranean. New evidence for oceanic thrusting before obduction Earth and Planetary Sci. Let., 52, 302-310.

Yağmurlu, F., Poisson, A., Bozcu, A., Şentürk, M., 2007. Isparta Açısının tektonostratigrafik özellikleri ve petrol jeolojisi açısından irdelenmesi. Türkiye 16 .
Uluslararası Petrol ve Doğalgaz Kongre ve Sergisi, Proceedings, s 10, Ankara. 